\title{
Westernization and The Transmogrification of Sailor Moon
}

\author{
Rhea Ashley Hoskin \\ Queen's University
}

\begin{abstract}
Sailor Moon, a Japanese series grounded in manga and anime, began airing translations in the West throughout the 1990s. The series provided what could be interpreted as resistance to dichotomous conceptualizations of sexuality, sex and gender. The focus of this article is the set of challenges presented by the genderqueer characters in Sailor Moon and how Westernization and English translations have worked to erase and re-write queer identities. Arguably, Sailor Moon acts as a site to play out the contextualities and complexities of sexuality, sex and gender identities. To name Sailor Moon characters in Western specific terms would be at the expense of reducing the complexity of their identities to a categorical system whose boundaries detract and limit meaning. Queer characters in Sailor Moon are not translatable into dichotomous Western thought - categories fail us and, through their enforcement, the depth of meaning and the complexities of queer identities/desires are lost in translation. Working within Western binary systems, categories and language, many of these identities appear contradictory and incoherent. Sailor Moon characters offer a re-envisioning of identities that is not limited by Western binaric thought and cannot be easily pegged within the heterosexual matrix.
\end{abstract}

Keywords: gender, sexuality, Sailor Moon, anime/manga, censorship, westernization

\section{Introduction}

The tradition of bifurcated thought is heavily influenced by Renee Descartes, who divided all of reality into "conscious subjects" and "mere bodies" - otherwise known as mind/body dualism (Bordo). Operating within Western systems of thought, cultural intelligibility relies on dichotomous pairings. These dichotomies prop up much of Western thought and are largely the framework through which Western society derives meaning. One of many social expressions of discursive dualities is that, while some groups have been awarded subject-status and protections, others have regularly and systematically been denied those protections, stripped of their "dignifying, and humanizing subjecttivity" and erased from the public view (Bordo). The current paper will examine the function of discursive binaries in maintaining Western heteronormativity through the translation and transmogrification of Sailor Moon. This paper will demonstrate how discursive practices are carried out through exclusions and erasure within cultural imagination and representation of what constitutes proper subjectivity.

Sailor Moon, a Japanese series grounded in manga and anime, began airing translations in the West throughout the 1990s (Grigsby 59). Though there are slight variations of timelines, Sailor Moon was cancelled between 1997-2003, depending on the location and network. Sailor Moon is both the title of the show and the name of the protagonist who, along with the other Sailor Scouts, are brought to Earth from the future to protect it against evil. The Sailor Scouts each have alias-human bodies as well as names and can transform into their respective superhero form when summoned. The show had a large audience base, as it was not only equally popular among girls and boys, but also appealed to adults, which made up 22 - 38\% of the viewers ('Sailor Moon among YTV's Top 40 Shows'). 
According to YTV, a leading Canadian broadcaster in the 1990s, of its 177 shows, Sailor Moon ranked among the top 40. Despite this popularity, the 5th and final season of Sailor Moon, which involved the Sailor Stars, was never dubbed or adapted for presentation in English to a North American audience. The cancellation of the show led fans of the show to launch the S.O.S. (Save Our Sailors) campaign, asking the networks to continue airing the show. The networks stood by their decision to stop translating the show into English, a somewhat mysterious decision given its extreme popularity.

Initially, the series seems recognizably heteronormative and conducive to the maintenance of heterosexual congruencies (Hoskin Femme theory). The term heterosexual congruencies refers to the cultural aligning of sex, gender and sexualities in ways that are thought to remain consistent and unchanging (Hoskin Femme theory). For example, a feminine female that is heterosexual, whose sexuality, sex and gender have always remained stable and unchanging, would represent the notion of heterosexual congruency. Within the series, Sailor Moon, the main protagonist, appears to fit this model of heterosexual congruency. Sailor Moon has a distinctly male boyfriend and, along with her friends - the other Scouts, she is portrayed as being "boy-crazed." A cursory examination of the storylines and characters can lead to the conclusion that the show presents characters who all appear to have stable sexes, genders and who are unquestionably heterosexual. However, upon closer inspection of the original and complete Japanese version of the entire Sailor Moon series, it becomes clear that the show contains many queer characters, relationships and a consistent blurring of the dichotomous boundaries concerning sex, sexuality and gender.

Unfortunately, the queer characters, relationships and depictions of gender fluidity were censored from the North American version of Sailor Moon as a result of decisions made by Optimum Productions, the Canadian company who produced the English version of Sailor Moon. Optimum claimed that the censorship of storylines and characters in the original Japanese version of Sailor Moon was required in order to meet the standards set out by the Canadian Radio - Television and Telecommunications Commissions (CRTC; Wockner). Optimum justified this censorship as a way of ensuring a "product that is suitable for children" (Velasco). Despite this explanation, a spokesperson for the CRTC stated that the organization had no guidelines at the time concerning queer content for children's programing (Velasco). This article theorizes the reasoning behind Optimum Production's decision to censor queer content. In so doing, the current paper explores the discursive process through which queer sexualities, genders and sexes were erased and re-written for the Anglicized version of Sailor Moon and how these censorships can be linked to historical and symbolic methods of disciplining bodies that are deemed not to fit within the dichotomous bounds of heteronormativity.

Nearly two decades since Sailor Moon began airing in the West, Canadian psychologists continue to grapple with gender independent children. With ongoing debates percolating over the ethics of how to best treat gender diverse children, the ease with which Sailor Moon characters engage with sexual and gender fluidity might provide a good prescription for the Western world. Specifically, the characters 
of Sailor Moon provide insight and stand as examples to remedy the current Canadian controversies over gender independent children. For example, the current Canadian context debates whether or not stopping children from growing up to be trans is considered conversion therapy asking whether it might be better to take the wait and see approach, whereby children are allowed to simply explore their gender identity in a supportive environment. This exploratory gender approach is much like how the characters on Sailor Moon are allowed to explore their identities within the original series. Sailor Moon characters offer an alternate starting point to questions of sexual and gender identity; one that is focused on fluid gender expressions, self-determination and identities that are not requisite to pre-existing categories of sex and gender.

\section{Methodology}

The following article employs Queer, Trans and Foucauldian theoretical frameworks as well as tools of content analysis. Rather than grounding this content analysis in quantification, the current analysis focuses on the meaning of the text in order to explore the queer content in Sailor Moon and the implications of North American editorial decisions. This analysis was further achieved by reviewing the complete Sailor Moon series and comparing the subtitles (direct translation) to the dubbed English voice-overs. Comparative manifest content analysis was used for the initial phase, in which I described the explicit material of the two versions of Sailor Moon, followed by a latent content analysis of the underlying and layered meaning of the texts (Kirby et al. 155; Esterberg 172). Finally, the Queer 'scavenger' method of combining both interactive and discourse content analysis was used to build theory and provide explanation for the discrepancies between manifest analyses and to examine their discursive function (Kirby et al. 220; Dahl).

\section{Results: Revealing Queer Characters}

In the original Japanese version, Zoisite is in a relationship with Malachite, both of whom are readable as cisgender men. Zoisite is characterized femininely and appears to romantically orient toward men. In the English dubbed version Zoisite is turned into a woman, rendering the formerly queer relationship between the characters heterosexual. According to Optimum Productions, Zoisite was changed from male to female due to broadcaster's fears that viewers would intuit a "gay" relationship between the characters (Wockner).

The third of Sailor Moon's five seasons introduces the queer couple, Sailors Uranus and Neptune (English Earth names Amara and Michelle, respectively). Amara is depicted as presenting or identifying masculinely in her Earth form. She uses feminine pronouns but is frequently read as a man. When the character Amara is introduced, the other Scouts have crushes on her, thinking that she is a boy. Amara tells the girls that she does not remember ever saying she was a boy, at which point the Scouts question their sexualities and deny their attraction but are drawn with hearts in their eyes and rose petals in the wind whenever Amara is around. When Amara transforms into Sailor Uranus her masculine presentations turns feminine, essentially challenging the idea of a dichotomously 
bound, monolithic and static gender expression as well as the assumption of feminine passivity. Amara transforms from masculine to feminine in order to fight: it is in her feminine gender expression that she becomes a powerful fighter. This transformation undermines the hegemonic and femmephobic gender orderings that naturalizes the superiority of masculinity and maintains the assumed weakness of femininity (Blair and Hoskin "Experiences"; Hoskin Femme theory and "Femme Theory"; Serano).

Sailors Uranus/Amara and Neptune/Michelle are lovers. In the Japanese version the relationship between Amara and Michelle is evident. When dubbed over, Amara and Michelle are depicted as "Cousins" who are simply said to be "very close" (Wockner). The relationship between Amara and Michelle exemplify how the Westernization of Sailor Moon works to maintain heteronormativity and normative-bodies by erasing queer desire and identities.

Fisheye uses masculine pronouns, dresses as what might be considered a "woman" or feminine presentation and frequently refers to themself as a woman or girl. Fisheye is openly attracted to men and "passes" as a woman. Notably, the use of masculine pronouns may reflect cissexism and cisnormativity on the part of the translators who, through a biological determinist paradigm, have wrongly and problematically gendered Fisheye to reflect his/her/their sex as assigned at birth. As such, this article uses gender-neutral pronouns when referring to Fisheye.

Though Fisheye could be classified within Western cultural imaginaries as trans*, this category does not account for the complexities of their identity. In the series, Fisheye's non-binary gender-variance is made apparent, however these differences are masked once translated into English; the contrast between direct translation subtitles and the dubbed-voices demonstrate the deliberate erasure of queer-identities. For example, in season 4 Sailor Moon SuperS, episode "Mini ga daishiki!Oshare na Senshitachi / Clothes Call / Love Those Minis! The Fashionable Soldiers" (Satou), Fisheye is chosen to be an up-and-coming fashion designer's newest muse and model. In the direct translation, the designer states that Fisheye is a "miraculous person that surpasses genders." This scene is altered so that, instead, the fashion designer says to Fisheye, "you're beautiful and have a unique look" (Satou). Later in the original episode during a fitting with the Fashion designer, Fisheye rips off the garment to reveal a masculine/male-contoured chest. In the dubbed version, the view of Fisheye's chest is cut so that the audience can only see from the shoulders up. Fisheye is changed into a stably gendered woman in the English dub of the anime. Scenes demonstrating their bodily signs of masculinity are cut and cropped.

The next queer characters appear in the fifth season, Sailor Moon Stars, the point at which Sailor Moon was cancelled in the West. Arguably, it is also at this point in the series that the concealment of queerness became too complicated and the erasure of queer-identities through translation and editing, impossible. On their "home-planet" the Sailor Starlights are women and female-bodied. On Earth, they embody masculinity, male identities and sexually orient towards women. When they 
"transform" from their Earth male-bodies into Sailor Starlights, they return to female-embodiment. The transformation sequence of the Sailor Starlights begins with what may typically be understood as a masculinely/male contoured body. The viewer watches as the physical embodiment of the Sailor Starlights weave between dichotomized boundaries of sex, gender and sexuality, essentially positioning these characters against notions of stable identity. Fluid identities became so complicated in Sailor Moon that Optimum Productions could no longer erase their variance nor account for their complexity.

The characters in Sailor Moon play out the complexities of sexuality, sex and gender identities in a way that does not subscribe to Western binaries, nor the notion of stable identities bound by these categories. Furthermore, several characters may be readable as transgender, yet exemplify how this categorization would be at the expense of other identities. Working within binary systems, many of these identities appear contradicting and incoherent - confused because of their constant flux. Between English translations of Japanese depictions and processes of hegemony, their queerness is lost, erased and, eventually, taken off the air. English translations deemed "acceptable" by broadcasters could not account for the complexity of these identities, and the broadcaster's attempts at erasure became too convoluted.

\section{Bodies that Do Not Fit: Non-docility, Queers and Binary-Breakers}

The queer characters of Sailor Moon represent what Cherrie Moraga and Gloria Anzaldúa describe as "the queer groups, the people that don't belong anywhere, not in the dominant world nor completely within [their] own respective cultures," in short, those "who cross over, pass over, or go through the confines of the normal" (Moraga and Anzaldúa 222). These bodies do not fit and, for this reason, pose a threat to dominant systems of power (233). Margrit Shildrick (227) describes the threat of nonnormative bodies as "anxiety of an inherent fluidity" generated by the "unpredictability of a body that does not behave as [one's] own." Shildrick (227) explains that "it is as though [one's] own selfcontrol is at stake, as though [one's] own ability to draw boundaries of distinction between self and other [...] is put in permanent doubt." The Subject is therefore threatened by the Other, whose presence poses a symbolic endangerment by serving as a reminder of the "putative failure of [the Subject's] own boundaries of distinction and separation" (232). In this way, the queer characters of Sailor Moon threaten and expose the insecurity and vulnerability of conventions of normativity. Normativity's hold on "order, control, and self-determination is fragile and uncertain" and is maintained by strategies that uphold boundary structures (231).

Drawing from a Foucauldian model, docile bodies can be understood as those who either fit, may be subjected, used, transformed, improved or are easily malleable into hegemonic binary systems of normality (McRuer 20). Non-normative bodies do not fit and can be conceptually positioned against docile bodies. Historically, bodies that are not cohesive or undermine dominant structures have been disciplined. To this end, over the past two or three centuries bodies have been monitored "for signs 
of behavioural and physical difference that might impede on their productivity" with the intention of rendering these non-docile bodies complaisant within hegemonic systems of power (21).

Hegemonic systems of power, including dichotomous systems of thought and heterosexual congruencies, require docile bodies. A body that is docile does not challenge, go against or subvert dominant structures. Those bodies that are not complaisant with dominant structures pose a threat to dominant order. One means by which this threat is disciplined is through the erasure, representtation and invisibility of non-docile bodies. Michel Foucault (Discipline 8 ) argues that as punishment moved away from an immediate physical discipline it moved toward a "certain discretion in the art of inflicting pain, a combination of more subtle, more subdued sufferings" such as depriving non-docile bodies of their visible display. Rather than contributing to the production of "docile bodies," Sailor Moon "celebrates and proliferates images of unruly bodies" (Connell 212). Arguably, the denial of visibility through censorship functioned as a disciplinary sanction by normative rule.

Every system of power is presented with the same problem; a non-normative body that subverts the standard of normalcy (Foucault, Discipline 218). Discipline can be considered a "normalizing gaze" whereby surveillance monitors, classifies, conditions and establishes a visibility through which one is differentiated and then judged (184). It is a means of training bodies (231). From a Foucauldian perspective, the censorship and subsequent erasure of non-normative bodies and identities is a form of discipline. Specifically, this discipline pertains to the ways in which non-docile bodies are kept suppressed or erased from the public view. In this way, discipline is a tactic to assure the "ordering of human multiplicities" (218). However, power does not simply repress, it constructs by producing "knowledge, categories, and identities that manage and regulate behavior" (Spade 318). The erasure and normalizing of queer characters in Sailor Moon demonstrates a mechanism of social forces that functions to prop up a "naturalized version of the sexual boundary" and promotes norm abiding gendered subjects (315). Sailor Moon serves as a site of resistance against these systems and, as such, demonstrates how popular culture can serve as a site of resistance against binary systems of hegemonic heterosexual congruencies.

In challenging systems of hegemonic heterosexual congruencies, the characters of Sailor Moon call assumed naturalized orderings into question, forcing the viewer to consider how such orderings became naturalized and to begin re-imagining alternative possibilities (McRuer 2). Moreover, the system of compulsory heterosexuality depends on a queer existence that is contained: i.e., the hetero/homo binary. Failing to adhere to the "hetero/homo" binary through the fluidity of sexes and genders of its characters, Sailor Moon threatens to expose queer existences that can never quite be contained within this binary, illustrating how heterosexual hegemony is always in danger of collapse (31). Non-normative bodies, whose existence cannot be securely placed in polarized categories, expose the permeability of said boundaries (Shildrick 224). As demonstrated within Queer theory, normalcy is maintained through compulsion and repetition (McRuer 7). By upholding normalcy 
through the erasure of queer identities that cannot be situated within binaries, the cessation of Sailor Moon works to promote and maintain compulsory heterosexual congruencies.

Furthermore, the distinctions between cultural binaries (e.g. hetero/homo, cis/trans, male/female, and so on) require ongoing maintenance in order to uphold them as "discrete" categories. The censorship of existences between binary distinctions, such as those in Sailor Moon, reveals the maintenance necessary to uphold assumed natural orderings and serves as a threat to dominant powers (Shildrick 225). Consequently, this risk has been culturally "negotiated with a strict set of normative rules and regulations that construct the parameters of safety and danger" (225). Having no guideline for queer content in children's television, yet maintaining social rules of keeping queer content away from children's developing imaginations, represents this normative rule of risk management. Furthermore, normativity's hold on "order, control and self-determination is fragile and uncertain, maintained only by strategies that hold at bay those others whose own corporeality re-awakens intimations" of the possibilities that exist and move between naturalized binaries (231).

\section{Resistance, Power and Voices from the Margins}

Practices of exclusion are discursive (Foucault History). Discourse is transformative in that where there is power there is resistance - the two constantly in flux and informing one another. In this way, power relations are inherently unstable as they continuously spawn new opportunities for transformation, putting hegemony in a perpetually precarious state (Bordo 28). While discourse is a productive power, Foucault also noted the "politically transformative possibility of counter-discourse," encouraging those who have been silence, erased or otherwise marginalized to begin to articulate their subjectivity and "counter the domination of prevailing authoritative discourses" (as cited in Connell 212). Counter-discourse moves beyond productive power, recognizing the transformative power of voices from the margins and how they "can change discourse through the circulation of what Foucault calls 'Subjugated Knowledges'" (Connell 212).

Power relations continuously spawn "new forms of culture and subjectivity," and "new opportunities for transformation" (Bordo 27). Dominant discourses are continuously renegotiated and reconstructed by resistance from the margins. Change, however, emerges gradually as both power and resistance remain in constant dialogue, continuously informing one another and creating minute shifts in power (Foucault History; Bordo). Power produces and normalizes bodies to "serve prevailing relations of dominance and subordination" (as cited in Bordo 26). Representations, along with discourses of sex(ual) embodiment, homogenize and "smooth out" all differences that disturb expectations and identifications. These homogenized images normalize - that is, they function as models against which the self is continually measured, judged and corrected (Bordo). As such, what is visible constructs the norm through repetition and compulsion. Teleologically, then, exploring multiplicities should serve to break away from binary logistics and compulsive repetitions. 
However, breaking away from binary logic cannot be achieved through the invocation of multiplicity alone. Challenges to dualistic frameworks require that we bring the margins to the center and that we "legitimate and nurture, in those institutions from which they have been excluded" (41). The practice of bringing marginalized aspects of ourselves and society into central areas of culture not only transforms these aspects, but makes these aspects transforming (Bordo). Largely falling outside of even normative hetero/homo identities, the queer characters of Sailor Moon are abjected from the Western world and expelled from the cultural imaginary. Characters such as the Sailor Starlights, who weave between Western notions of the proper self, are abject bodies who threaten to breakdown meaning by disturbing order and systems of identity. They do not "respect borders, positions or rules" of cultural intelligibility (Kristeva 4). Queer characters of Sailor Moon not only offer sexual and genders that break away from discursive binaries, they also have the ability to bring marginalized voices into mainstream popular culture - to bring the margins to the centre. The showcasing of marginalized voices promotes changes in consciousness. Not only are these changes to life, in a culture that "counts on our remaining unconscious" these changes are equally political (Bordo 30). By carving-out a space of belonging for those abjected from dominant imaginaries, while simultaneously engaging the mainstream culture in a highly visible and popularized forum, the characters of Sailor Moon are particularly dangerous. If "normal" is constructed and discursively maintained through repetition, the queer characters of Sailor Moon disrupt this repetition on a large scale and to a broad, mainstream audience.

\section{Discussion}

Although many who study Japanese culture describe manga/anime as targeting an older audience, the question still beckons; why are heterosexual love narratives acceptable and not censored, as in those between Darien and Serena (Tuxedo Mask and Sailor Moon)? What makes love narratives between various genders and sexes less appropriate for younger audiences? Why are such relations and identities only understood within a pornographic and deviant framework? These questions are especially pertinent considering The Children's Charter, which was created at the World Summit on Media For Children, and was used in the development of legislation such as the Children's Television Act (Home). The Children's Television Act is endorsed by 38 countries, and mandates for children's television to "promote an awareness and [appreciation] of other cultures" (Home). Equally perplexing is the Youth Media Alliance, whose mission is to provide content of productions that stimulates "the intellect and imagination, and [fosters] openness to others as well as [allowing] children and teens to explore the world beyond their immediate experience (their family, friends, school, street, city, society, world and universe)" (2012). Neither the Children's Television Charter, the Youth Media Alliance nor the CRTC formally take issue with queer content in children's television. Yet, societal discomfort with any queer signifiers in children's television remains prominent. Take, for example, the outrage over the intuited queerness of Teletubbies' Tinky Winky, who sported a triangular aerial, wore purple and carried a purse; Sesame Street's Bert and Ernie, whose homosociality was, for many, a cause for concern; Spongebob Square Pants whose caring relationship with Patrick prompted discussions of the pathological implications for developing minds; and Shark Tale's subtext of 'closeted' desires and 
identities. These are merely a few modern examples of queer sub-text in children's media that sparked outrage. Such examples demonstrate the extent of social discomfort and covert homophobia over the intuited queerness within loving relationships. While heterosexual narratives and violence are naturalized, the positive messages and acceptance of differences are deemed inappropriate for developing minds.

Recent studies such as those conducted by California Safe Schools Coalition (Burdge et al.), show that the inclusion of diversity into the education system creates a safer space for all students - not simply those whose identities have been kept marginalized within the larger society. Furthermore, some have suggested that comic and manga/anime's unconventional narratives "give its female audience more agency" and offers safe opportunities to "experiment with different sexual and gender roles" (Goldstein and Phelan). Conversely, Moraga and Anzualda (104) write that, "when patriarchy dismisses us, it encourages our murderers." Indeed, the erasure, eradication and invisibility of queer characters sends a specific message to queer youth. Recent work by Blair and Hoskin ("Experiences" and "Contemporary Understandings") demonstrates the impact of invisibility and a lack of representtation on identity formation. How can a society claim to be concerned over queer suicides, while simultaneously erasing the existence of queer role models from youth television? From characters who might be understood as lesbian, bi, gay or trans, and even depictions of queer-parenthood: Sailor Moon offers what could potentially be a positive depiction of diversity so badly needed for Western youth of the 1990s as well as the gender-independent children and youth of today.

\section{Conclusion}

Sailor Moon functions as resistance to dichotomous conceptualizations of sexuality, sex and gender; offers a re-envisioning of gendered/sexed categories; and gives space to queer youth to understand the complexity of identities by opening-up possibilities for creating their own. However, to name Sailor Moon's characters in Western specific terms would be at the expense of reducing the complexity of their identities to a categorical system, whose dichotomous boundaries detract and limit meaning. Queer characters in Sailor Moon are not translatable into dichotomous Western thought categories fail us and, through their enforcement, the depth of meaning and complexities of queer identities and desires are lost in translation. It is this fluidity, the blurring of Western boundaries, that provokes cultural anxiety. The characters in Sailor Moon offer a re-envisioning of identities that are not limited by Western binaric thought, as they cannot be easily pegged within the heterosexual matrix (Butler). The re-writing of cultural categories of normalcy poses a symbolic threat to the assumed naturalized order: systems of power require docile-bodies. As demonstrated by the original series of Sailor Moon, these characters do not contribute to docility but, instead, celebrate "unruly" and "abjected" notions of self. Resultantly, and despite the potential benefit to youth, the series was censored, edited and finally taken off the air. 


\section{Works Cited}

Allison, Anne. "A Challenge to Hollywood? Japanese Character Good Hit the US." Japanese Studies 20.1 (2000): 67-88. Print.

Blair, Karen Lyndsay, and Rhea Ashley Hoskin. "Contemporary Understandings of Femme Identities and Related Experiences of Discrimination." Psychology and Sexuality 7.2 (2016): 101-115. Print.

------. "Experiences of Femme Identity: Coming Out, Invisibility, and Femmephobia." Psychology \& Sexuality 6.3 (2015): 229-244. Print.

Bordo, Susan. Unbearable Weight: Feminism, Western Culture and the Body. Berkeley: U of California $P, 1993$. Print.

Burdge, Hilary, et al. "Lessons That Matter: LGBTQ Inclusivity and School Safety." Gay-Straight Alliance Network and California Safe Schools Coalition Research Brief No. 14. San Francisco, CA: Gay-Straight Alliance Network (2012): 1-8.

Butler, Judith. Gender Trouble: Feminism and the Subversion of Identity. New York: Routledge, 1990. Print.

Connell, Catherine. "Fashionable Resistance: Queer 'Fa(t)shion' Blogging as Counterdiscourse." Women's Studies Quarterly 41.1\&2 (2013): 209-224. Print.

Cornog, Martha, and Timothy Perper. "Non-Western Sexuality Comes to the U.S.: A Crash Course in Manga and Anime for Sexologists." Contemporary Sexuality 39.3 (2005): 4-6. Print.

Dahl, Ulrika. "Femme on Femme: Reflections on Collaborative Methods and Queer Femme-Inist Ethnography." QueerScope Articles 1 (2011): 1-22. Print.

Esterberg, Kristin. Qualitative Methods in Social Research. Boston: McGraw-Hill Higher Education, 2002. Print.

Foucault, Michel. Discipline and Punish: The Birth of the Prison. New York: Vintage Books, 1979. Print.

------. The History of Sexuality: An Introduction. Volume 1. New York: Vintage Books, 1978. Print.

Gauntlett, David. Media, Gender and Identity: An Introduction. New York: Routledge: 2002. Print.

Goldstein, Lisa, and Molly Phelan. "Are You There God? It's Me, Manga: Manga as an Extension of Young Adult Literature." American Library Association, Young Adult Library Services 7.4 (2009): 32-38. Print.

Grigsby, Mary. "Sailormoon: Manga (Comics) and Anime (Cartoon) Superheroine Meets Barbie: Global Entertainment Commodity Comes to the United States." The Journal of Popular Culture 32.1 (2003): 59 -80. Print.

Home, Anna. The Children's Television Charter. The World Summit on Media for Children Foundation, 1995. Web. 28 Aug. 2012. <http://www.wsmcf.com/charters/charter.htm>.

Hoskin, Rhea Ashley. Femme theory: Femininity's Challenge to Western Feminist Pedagogies. Master's thesis. Kingston, Ontario: QSpace at Queen's University, 2013. ii-168. Print.

------. "Femme Theory: Refocusing the Intersectional Lens." Atlantis: Critical Studies in Gender, Culture, \& Social Justice 38.1 (2017): 95-109. Web. 9 May 2019.

<http://journals.msvu.ca/index.php/atlantis/article/view/4771/95-109\%20PDF>. 
Kirby, Sandra, Lorraine Greaves, and Colleen Reid. Experience, Research, Social Change: Methods Beyond the Mainstream, $2^{\text {nd }}$ edition. Toronto: Broadview Press, 2006. Print.

Kristeva, Julia. Powers of Horror: An Essay on Abjection. Trans. Leon Roudiez. New York: Columbia UP, 1982. Print.

McClintock, Anne. Double Crossings: Madness, Sexuality and Imperialism. Vancouver: Ronsdale Press, 2001. Print.

McRuer, Robert. Crip Theory: Cultural Signs of Queerness and Disability. New York and London: New York UP, 2006. Print.

Moraga, Cherríe Lawrence and Gloria Evangelina Anzaldúa. This Bridge Called My Back: Writings by Radical Women of Color. Berkeley: Women of Color Series, Third Woman Press, 2001. Print.

"Sailor Moon Among YTV's Top 40 Shows." The Gazette. Informart, a Division of Postmedia Network Inc., 1997. Web. 26. Oct. 2013.

Satou, Junichi. "Mini ga daishiki! Oshare na Senshitachi / Clothes Call / Love Those Minis! The Fashionable Soldiers / Episode 140." Sailor Moon SuperS, Season 4, Television Program, 1995/2000. TV Asahi - Kenji Ohta. Original air date 1. July 1995. English air date 12. Oct. 2000.

Sebert, Paul. "Kissing Cousins May Bring Controversy: Cartoon Network Juggles Controversial Topics Contained in the Sailor Moon S Series." The Daily Athenaeum and The Daily Athenaeum Interactive, 28 June 2000. Web. 29 Aug. 2012.

<http://web.archive.org/web/20080208132910/http://www.da.wvu.edu/archives/002806/news/ $002806,07,01 . \mathrm{html}>$.

Serano, Julia. Whipping Girl: A Transsexual Woman on Sexism and the Scapegoating of Femininity. Emeryville, CA: Seal Press, 2007. Print.

Shildrick, Margrit. "Dangerous Discourses: Anxiety, Desire, and Disability." Studies in Gender and Sexuality 8.3 (2007): 221-244. Print.

Spade, Dean. "Mutilating Gender." The Transgender Studies Reader. Ed. Susan Stryker and Stephen Whittle. New York: Routledge, 2006. 315-332. Print.

Velasco, Ab. "Sailor Moon's Pals go Straight: Canadian Version of Kids Show Dumps Lesbian Lovers." Xtra, Pink Triangle Press, 2000. Web. 20 Aug. 2012.

<http://archives.xtra.ca/Story.aspx?s=1409570>.

Wockner, Rex. "Lesbians Edited from Japanese Cartoon." Bay Windows, 2000. LGBT Life with Full Text (EBSCO). Web. 20 Aug. 2012. < https://www.ebsco.com/products/researchdatabases/lgbt-life-full-text>.

Youth Media Alliance. "Mission." Web. 28 Aug. 2012. <http://www.ymamj.org/a_propos_en.html>.

\section{Westernizacja i przeobrażenia Sailor Moon}

Sailor Moon (Czarodziejka z księżyca), Japoński serial oparty na mandze i anime, zacząt wchodzić na zachodnie ekrany z ttumaczonymi napisami w latach 90. XX w. Serial ten wprowadzat coś, co można interpretować jako opór wobec binarnych koncepcji seksualności, ptci biologicznej i ptci kulturowej. Niniejszy artykut opisuje wyzwania stawiane widowni przez queerowe postaci Sailor Moon, a następnie ukazuje, jak westernizacja $i$ angielskie tłumaczenia napisów wymazywały i przepisywaty na nowo nieheteronormatywne tożsamości. 
Wedtug autorki, Sailor Moon stanowi przestrzeń dla złożonych, kontekstualnych tożsamości seksualnych i ptciowych. Nadawanie postaciom z Sailor Moon imion zgodnie z zachodnimi konwencjami wymagatoby zredukowania ich złożonych tożsamości do systemu kategorii ograniczających znaczenie. Ponieważ tożsamości odmieńców w Sailor Moon nie da się prowadzić do dychotomicznych kategorii ptci i seksualności przyjętych w zachodnim świecie, gtębia potencjalnych znaczeń i różnorodność nieheteronormatywnych tożsamości oraz rodzajów pożadania zostaja utracone $w$ tłumaczeniu. Wiele z tych tożsamości, wttoczonych w zachodnie binarne systemy i kategorie językowe, cechuje wewnętrzna sprzeczność i niespójność. Oryginalne postaci z Sailor Moon umożliwiaja nowe spojrzenie na tożsamości, nieograniczone zachodnim binarnym myśleniem i niepasujace do heteroseksualnej matrycy.

Stowa kluczowe: gender, seksualność, Sailor Moon, anime/manga, cenzura, westernizacja 